From Media Hype to Twitter Storm 



\title{
From Media Hype to Twitter Storm
}

News Explosions and Their Impact on Issues, Crises, and Public Opinion

\author{
Edited by \\ Peter Vasterman
}


Cover illustration: Alain Delorme, MURMURATIONS Ephemeral Plastic Sculptures \#2. www.alaindelorme.com

Cover design: Coördesign, Leiden

Lay-out: Crius Group, Hulshout

Amsterdam University Press English-language titles are distributed in the US and Canada by the University of Chicago Press.

$\begin{array}{ll}\text { ISBN } & 9789462982178 \\ \text { e-ISBN } & 9789048532100 \\ \text { DOI } & 10.5117 / 9789462982178 \\ \text { NUR } & 811\end{array}$

(C) P. Vasterman / Amsterdam University Press B.V., Amsterdam 2018

All rights reserved. Without limiting the rights under copyright reserved above, no part of this book may be reproduced, stored in or introduced into a retrieval system, or transmitted, in any form or by any means (electronic, mechanical, photocopying, recording or otherwise) without the written permission of both the copyright owner and the author of the book.

Every effort has been made to obtain permission to use all copyrighted illustrations reproduced in this book. Nonetheless, whosoever believes to have rights to this material is advised to contact the publisher. 
It is not difficult to see the similarities between massive starling flocks, flying as one and creating new shapes - murmurations - and the way media operate during explosive news waves, the main topic in this book. 
